\title{
OPĚTOVNÝ NÁLEZ JEDNÉ NEJSTARŠÍCH UČEBNIC HARMONIE V ČEŠTINĚ
}

První polovina 19. století přinesla do Prahy změnu dosavadního paradigmatu hudebně teoretického vzdělávání prostřednictvím založení pražské konzervatoře (1811) a varhanické školy (1830). Tomu odpovídá i postupná proměna produkce teoretických spisů: od osvíceneckých pojednání představující fenomén hudby a její teorie především intelektuálům a nadšeným diletantům směrem ke konkrétněji zaměřené literatuře učebnicového typu. Vzhledem $\mathrm{k}$ tomu, že rozbor skladeb a hudební formy v pravém slova smyslu u nás byly kolem poloviny 19. století ještě ve stadiu zrodu (nebo spíš ve stadiu „prenatálním“), hrála logicky klíčovou úlohu harmonie.

První vydaná učebnice harmonie v češtině, Theoreticko-praktická nauka o harmonii pro školu a di̊m, pochází z pera Františka Blažka (1815-1900). Publikována byla $\mathrm{v}$ Praze $\mathrm{v}$ roce 1866, nicméně dokončena byla už roku 1850 a reálně byl její obsah už na varhanické škole přednášen. Vydání zdržely společenské události následující po revolučním roce $1848 .{ }^{1}$

\section{Dosavadní literatura, hypotézy o autorství}

Podle dostupných zpráv by však měla, alespoň v nevydané podobě, existovat učebnice harmonie $\mathrm{v}$ českém jazyce srovnatelného stáří. Jejím autorem měl být Josef Krejčí (1822-1881), pozdější ředitel varhanické školy (1858-1866) a konzervatoře (od 1866), který od roku 1848 zastával místo učitele varhanictví a harmonie na české hlavní škole, jejímž úkolem mimo jiné byla výchova budoucích učitelů a tedy i zajištění odpovídajícího hudební vzdělání. Zřejmě právě pro tyto potřeby měla vzniknout roku 1849 Krejčího Nauka o romonu čili harmonii pro hudebníky, přičemž nezanedbatelnou úlohu v celém procesu hrál i tehdejš́ ř ředitel školy Karel Slavoj Amerling.

Srov. LUDVOVÁ, Jitka. Česká hudebni teorie novějši doby: 1850-1900. Praha: Academia, 1989, s. 66. 
Vzhledem k tomu, že autograf učebnice byl dosud považován za nezvěstný (viz níže), sledujme nejdříve stopu tohoto spisu v literatuře. Nejnovější širší zmínka o Krejčího nezvěstné učebnici harmonie pochází ze studie Jitky Ludvové Česká hudebni teorie 1750-1850. Vzhledem k tomu, že bude postupně potřeba reagovat na více jeho částí, uved'me záznam z autorčina soupisu pramenů celý:

\begin{abstract}
„Krejčí, Josef (?)[sic]: Nauka o romonu čili harmonii pro hudebníky. Praha 1850. Nákladem K. S. Amerlinga. [Nedokončeno.]

Tento bibliografický údaj uvádí Douchưv Knihopis (s. 114). O tisku se zmiňuje i Riegrův Slovník $v$ hesle Josef Krejči: , 1848 povolán za učitele praktického varhanictví a harmonie na nově zř́zenou českou hlavni školu, kde pưsobil po tři léta. Počna vydávati Nauku o harmonii v jazyku českém, byl v tom brzy zastaven nedostatkem peněz a opatřením vlády, která jeho místo na hlavni škole zrušila. “ Čs. hudebni slovnik, heslo Jos. Krejčí, uvádi, že „vydal prvni českou nauku o harmonii, 1849, nedok". - Vydanou verzi nedokončené harmonie se nepodařilo nalézt. Obsah známe pouze od Otakara Šina, který ve Sborníku na pamět' 125 konzervatoře (1936, s. 165) reprodukuje tři paragrafy z Nauky o romonu. Rukopis se v roce 1936 nalézal v Krejčího pozůstalosti na konzervatoři, podle sdělení archiváře se tam však dnes [tzn. v polovině 80. let - pozn. VH] už není. - Ačkoli Šín naprosto nepochybuje o Krejčího autorství, zůstává nad ním otazník. Odborná terminologie vykazuje totiž neobyčejně nápadnou podobnost s nezaměnitelným názvoslovím Amerlingovým (romon, tónec, tóncový soubor, tvrdé potóní). Existuji i obsahové shody mezi mezi údajným Krejčiho fragmentem a Amerlingovým textem z roku 1851 (T-15). Definitivni rozhodnutí této otázky by umožnilo pouze posouzeni pisma na nezvěstném autografu.“2
\end{abstract}

Z uvedeného vyplývá, že Otakar Šín měl v období mezi válkami spis fyzicky $\mathrm{k}$ dispozici. Podle jeho vlastních slov ovšem ani tehdy nešlo o celou práci, ale pouze o fragment: „Z malého zbytku rukopisu Josefa Krejčího [...] soudě, chtěl věhlasný reditel konzervatoře napsati ,Nauku o romonu čili harmonii. “. ${ }^{3}$ Dále reprodukuje čtyři ${ }^{4}$ paragrafy z části spisu, kterou měl k dispozici, opět je užitečné uvést tuto neprŕliš dlouhou pasáž kompletní:

„V § 1. vysvětluje autor slovo ,romon 'jako staroslovanský název stejného významu jako ,harmonie؛ Podobně zavádí i jiné české názvy, na př. ,tonáda - tónina, ,tónec - tónika, ,tónice“ - dominanta, ,nizotónice'- subdominanta, ,prva' - prima, ,vtera' - sekunda, ,treta' - tercie atd., ,osma'-oktáva, , mezina'-interval.

$V \S 2$. jedná o, Vynalezeni a uspořádání romonu př́rodou poskytnutého'. Odvozuje trojzvuk $z$ přirozené rady aliquotnich tónů. Tónický kvintakord nazývá ,tóncovým soutónem ' (akordem nebo ,trojtónem '), dominantní-, tónicovým', subdominantni -, nizotónickovým soutónem:

$\S$ 3. jedná ,O romonu tvrdého potóní (stupnice) ve čtverhlasé sadè, o zdvojení tónů v soutóních, o vynalezeni soutónů k úplnému doprovázeni tvrdého potóni".

,§ 4. Zkoušení a opravení soutónů: a) čtverhlasá sada, b) souvislost soutónů, c) chybná postupování osmami a pátami ."“5

2 LUDVOVÁ, Jitka. Česká hudební teorie 1750-1850. Praha: Academia, 1985, s. 85-86.

3 ŠÍN, Otakar. Teoretikové v řadě ředitelů pražské konzervatoře. In: . Sbornik na pamět' 125 let konzervatoře hudby v Praze. Praha: Vyšehrad, 1936, s. 168.

$4 \quad$ Nikoli tedy tři, jak uvádí Ludvová. Na celkovém vyznění bádání obou ovšem tento detail de facto nic nemění.

5

1.c. 
Výše uvedené shrnutí končí konstatováním, že: „Dále rukopis nejde. Zajímavé je na něm zčeštováni názvosloví, o němž se i Pavel Josef Šafařík pochvalně vyjádřil." “6

Nejasná je v tomto př́padě úloha pedagoga, přírodovědce a filozofa Karla Slavoje Amerlinga (1807-1884), jehož spojitost se spisem by mohla zřejmě být jak autorské, tak vydavatelské povahy. Nebudeme na tomto místě prŕiliš rozšiřovat tento text o jeho medailon. Potřebná vybraná fakta obsahují odstavce níže a př́ipadné zájemce o širši informace lze odkázat např́klad na zmíněnou studii Jitky Ludvové Česká hudebni teorie 1750-1850, monografii Evy Hoffmannové Karel Slavoj Amerling ${ }^{7}$ nebo na dvojici mých textů, a to jednak na mou diplomovou práci ${ }^{8}$ nebo na popularizační studii Karel Slavoj Amerling v kontextu své doby. ${ }^{9}$

Lze se velmi dobře domnívat, že o otázce autorství by bylo možné rozhodnout i nepřímo, tj. bez grafologického posudku autografu, který pro „definitivní rozhodnutí otázky“ nárokuje Jitka Ludvová. Možnost Amerlingova autorství by se dala vyloučit i prokázáním, že dotyčný ve skutečnosti neměl znalosti a dovednosti potřebné $\mathrm{k}$ sepsání nauky o harmonii. Takový důkaz jsem provedl v rámci své diplomové práce, ${ }^{10} \mathrm{kde}$ je možné si jej projít detailněji, zde uved’me pouze základní osu:

Všechny Amerlingovy publikované práce, které by se daly označit za hudebně teoretické, mají ve skutečnosti bud' popularizační (např. Př́spěvek $k$ mudřectví hudebnimu dle Frančana Fétise ${ }^{11}$ ) nebo pedagogický rozměr (např. O hudbě $z$ hlediště vychovatelského ${ }^{12}$ ). Pokud byl Amerling na poli hudební teorie kreativní, pak to bylo pouze $\mathrm{v}$ oblasti názvoslovné, kde byl autorem mnoha až přehnaně květnatých novotvarů, nebo byly jeho teorémy per analogiam založeny na znalostech z odlišných vědních oborů (např. krystalografická klasifikace tónin ${ }^{13}$ ). Zcela samostatnou kapitolu pak tvoří jeho filozofické práce, ve kterých se hudba a její teorie vyskytují v postavení nikoli nepodobném určitým odnožím středověké musica speculativa ${ }^{14}$ - hudba je abstrahována nad svět znějících zvuků.

$6 \quad$ 1.c.

7 HOFFMANNOVÁ, Eva. Karel Slavoj Amerling. 2. vyd. Brandýs nad Orlicí: Knihkupectví U Podléšky, 2003.

8 HRUŠKA, Viktor. Dílo vybraných osobností počátků dějin české hudební teorie. Praha, 2013. Diplomová práce. HAMU.

9 HRUŠKA, Viktor. Karel Slavoj Amerling v kontextu své doby. Živá hudba. 2012, č. 3.

10 Srov. HRUŠKA, Viktor. Dílo vybraných osobnosti počátků dějin české hudebni teorie, s. 6768 a s. $70-71$.

11 AMERLING, Karel Slavoj. Příspěvek k mudřectví hudebnímu dle Frančana Fétise. Jindy a nyní. 1833, s. 8-9.

12 AMERLING, Karel Slavoj. O hudbě z hlediště vychovatelského. Posel z Budče. 1848, s. 4852.

13 Srov. např. HRUŠKA, Viktor. Dílo vybraných osobností počátků dějin české hudební teorie, s. 55-57.

14 Tato paralela není zvolena náhodně, Amerling hudební teorii skutečně do tohoto postave- 
V žádné ze svých prací se Amerling nedotkne řešení konkrétního kompozičního problému, ani ve smyslu cvičení. Naopak, obsah pramene Hudba českoslovanská z Amerlingovy pozůstalosti uloženého v Literárním archivu Památníku národního písemnictví, ${ }^{15}$ ve kterém se nacházejí schémata vizualizující příbuznost tónin, svědčí o pochybeních už v základech praktické hudební nauky, kterých se Amerling dopouštěl, byt' je nikdy nepublikoval. Závěr je zřejmý: Karel Slavoj Amerling dost dobře nemohl být autorem učebnice, jejíž osnovu Šín nastínil.

Nicméně, stejně tak lze snést přesvědčivé důkazy o tom, že zcela nezávisle na Amerlingovi Krejčího spis také vzniknout nemohl - přinejmenším je zde např́klad ono zmíněné „nezaměnitelné názvosloví“.

$\mathrm{K}$ řešení této a dalších nastíněných otázek se vrátíme níže. Bylo nutné projít těmito odstavci, protože teprve na jejich základě lze správně interpretovat znovuobjevený autograf Nauky o romonu čili harmonii pro hudebniky, který Jitka Ludvová v polovině 80 . let neměla to štěstí získat.

\section{Autograf Nauky o romonu}

Pozůstalost Josefa Krejčího se zřejmě v archivu pražské konzervatoře nacházela vždy, pouze $\mathrm{k}$ ní personál z nejasných důvodů neumožnil př́stup. ${ }^{16}$ Její teoretická část je poměrně obsažná, převažují vcelku samozřejmě prameny v němčině. Mezi několika českými texty se nicméně nauka o romonu skutečně nachází. Co víc, lze zde nalézt nejen její čistopis, ale také koncepty.

Š́n zjevně vycházel právě z čistopisu, který ovšem nepokrývá plný rozsah látky vyložené v konceptech. Krejčího učebnice se v něm logicky jeví jako torzo, nicméně koncepty jsou podstatně rozsáhlejší - Josef Krejčí svou učebnici dopsal, zřejmě pouze nikdy nezhotovil úplnější čistopis. Tento pramen také poskytuje definitivní stvrzení výše podaného důkazu: Josef Krejčí nejširší verzi konceptu (po odstavci $K$ ukončeni práce této) v Praze 15. června 1849 signoval.

Mimochodem, tímto bychom skutečně mohli mluvit o Krejčího učebnici harmonie jako o první svého druhu v českém jazyce - Blažkova byla zřejmě dokončena až o několik měsíců později. Takový spor o prvenství nicméně postrádá smysluplné jádro: Krejčí svou učebnici patrně nikdy nevydal a její stopu v dějinách české hudby mohly snad představovat pouze jeho vlastní hodiny, kde nic-

ní svým osobitým způsobem stylizuje. Nejvýrazněji asi v německy sepsané práci Der Gott des Christenthums als Gegenstand streng wissenscheftlicher Forschungvydané v Praze roku 1880. „Mudřectví hudby“ je vedle matematiky, psychologie a astronomie součástí jakéhosi quadrivia věd, které tvoří první a základní linii v poznávání světa. Viz HRUŠKA, Viktor. Dílo vybraných osobností počátků dějin české hudební teorie, s. 57-61.

Detailněji popsáno v HRUŠKA. Dílo vybraných osobností počátků dějin české hudební teorie, s. 61-67.

16 Odtud patrně také velmi dobře zvolené vyjádření Jitky Ludvové, že se v archivu dotyčná pozůstalost ,podle sdělení archiváre již nenacházi“. 


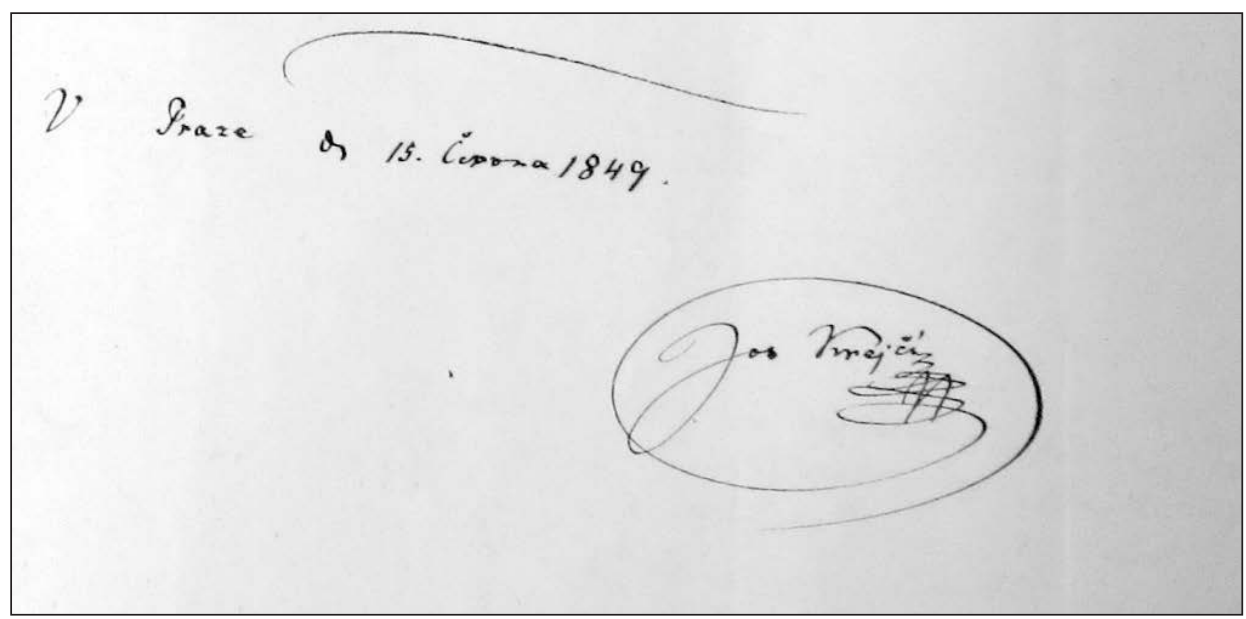

Obr. 1. Podpis Josefa Krejčího na poslední straně konceptu Nauky o romonu čili harmonii.

méně patrně nepoužíval nejosobitější část textu učebnice, totiž názvosloví (viz níže).

Rozdíl mezi Krejčího koncepty a neúplným čistopisem se nachází už na samotném začátku. V konceptu začíná Krejčí vcelku věcnou a úspornou pasáží (,Úlohou nauky o romonu jest ta, aby naučila více neb méně tónů současně upotřebovati, které na sluch náš přijemně oučinkuji. [...]“), která je součástí úvodní kapitolky Vynalezení romonu prírodou poskytnutého, která v souladu s dobovým územ stručně prochází nejzákladnější akustická fakta. Čistopis ovšem začíná následující pasáží, která co do slovní zásoby a vzletné stylizace z ostatního textu výrazně vyčnívá:

„Ačkoli slovo romon staroslovanského jest původu, předc ve světě hudebnickém méně jest známé což na divno nebudiž, nebot'v osudných stoletich slovanského životěni nebylo duchi̊, jenž by byli ušlechtilé toto odvětví krásných um vědecky a umělecky pěstovali. A však slovo romon neni méně srozumitelné nežli řecký dosud všudy známý název harmonia, nebot' oboje slovce romon a harmonia jsou pưvodu indoeuropejského, oznamenajice oboje zpěv zvučný a tedy provazený větším počtem hlasů líbezně souznivajicich.

Co do věci vyrozumivá celý vzdělaný indoeuropejský svět pod názvem romon ten oddíl krásné umy hudební, který se zanáši pravidelným a současným upotřebováním více hlasů ku dokonalejšimu výrazu nápěvnich čili melodických myšlenek hudebních.“

Spíš než konkrétní podobnost ve smyslu citace zde rozeznáváme Amerlingův národovecký styl a jeho nevyřčenou snahu dokázat, že jsme bývali velcí - rétorika nikoli nepodobná Rukopisům, jichž musel být Amerling oddaným čtenářem. Kromě toho je zde samozřejmě ještě jedna významná spojitost: jak uvádí už Jitka Ludvová, s výjimkou dvojice Krejčí-Amerling žádný český teoretik slovo romon nepoužíval. Vzdor svým tvrzením si tento svérázný termín na základě podobnosti souhlásek $r m n$, které spoluvytváří slovo harmonie, s největší pravděpodobností 
vymyslel Amerling sám. Jeho věty o „staroslovanském původu“ jsou tedy vlastně pokusem o romantické historické falzum.

V konceptech se nachází velké množství škrtů a poznámek na margínách, které jsou s největší pravděpodobností dílem více než jedné ruky. Lze se domnívat, že vedle Krejčího se na prípravě textu podílel právě Karel Slavoj Amerling. Tuto hypotézu lze kromě výše podaných nepř́mých důkazů podpořit dvěma dalšími skutečnostmi. Jednak různé př́ípisy vykazují grafickou podobnost ${ }^{17}$ např́klad s poznámkami $v$ textech přednášek $\mathrm{z}$ estetiky Franze Fickera, které Amerling absolvoval za svého studentského pobytu ve Vídni. Zmíněné texty přednášek jsou součástí pramene Hudba českoslovanská z jeho pozůstalosti. Krom toho často tyto poznámky cizí rukou nemírí $\mathrm{k}$ hudebně teoretickému meritu věci, ale právě tam, kde si byl Amerling relativně nejjistější, totiž k používanému názvosloví.

Autor poznámek v Krejčího učebnici právě tímto způsobem často měnil terminologii z pojmů německého, italského, latinského nebo řeckého původu na tvary až fanaticky české. Nadpis „Volnějšsi harmonizace podaných nápěvü byl tak např́ílad opraven na „Volnějši romoněni [...]“, namísto „chromatické průchody“ jsou vyžadovány ,drobnopotonní průchody“, věta z úvodu do části o zmenšeném septakordu (sedmého stupně) „Jak jsme nalezli z dominantního septim-akordu vynecháním základního tónu zmírněný trojzvuk [...]“, má podle korektury znít „Jak jsme nalezli z tónicového sedmo-akordu [...]“. Zde je navíc patrná nehomogenita názvosloví: „sedmní soutón“, „sedmo-akord“ a lze se setkat i se „sedmovým soutónem“, zkráceně „,sedmo-soutóny“. Autor př́ípisků rovněž opravoval Krejčímu některé stylistické chyby. Josef Krejčí si patrně svou formální psanou češtinou nebyl zcela jistý. $V$ pozůstalosti se nalézají např́klad poznámky obsahující překlady německých termínů do češtiny nebo vzorníky jejich českých gramatických tvarů, dokonce lze nalézt i dvojjazyčně psané strany německý originál-odpovídající český překlad. Fyzická velikost těchto poznámek jde od kartiček $\mathrm{a}$ až k celým listům. Na zadní straně jednoho z větších je jednoslovná poznámka „Šafaři $k^{\prime \prime}$ - zde zrejmá spojistost se „zčeštování[m] názvosloví, o němž se i Pavel Josef Šafařik pochvalně vyjádřill“ (viz výše citát z Šínova článku).

Opust'me téma autorství spisu a jeho historického pozadí vůbec a věnujme se více jeho obsahu. Mnoho odstavců existuje v Krejčího pozůstalosti ve více než jedné verzi, přičemž jejich následnost není místy zcela jasná. Následující přehled tedy není didakticky seřazen podle původního záměru.

Odstavce, které Š́n reprodukoval, tvoří relativně menší část v konceptu dochovaného celku. Samostatné odstavce Krejčí věnuje harmonii mollových tónin (romonu měkkého potóni), spojům akordů různého stupně př́ibuznosti (souvislosti), zacházení s citlivým tónem a tóničnímu-sedmnímu-soutónu (pozor, tónice znamená dominanta - jedná se tedy o dominantní septakord). Stejně tak se dostane na devítni soutóny, zmirněné (zmenšené) trojzvuky a sedmni-soutóny. Krejčí má dokonce snahu o vybudování úplnější systematiky akordů (odstavec Vynalezení všech možných volitelných soutónů). Vysoko nad úroveň základního informatoria

Rigorózní grafologická analýza nicméně provedena nebyla. 


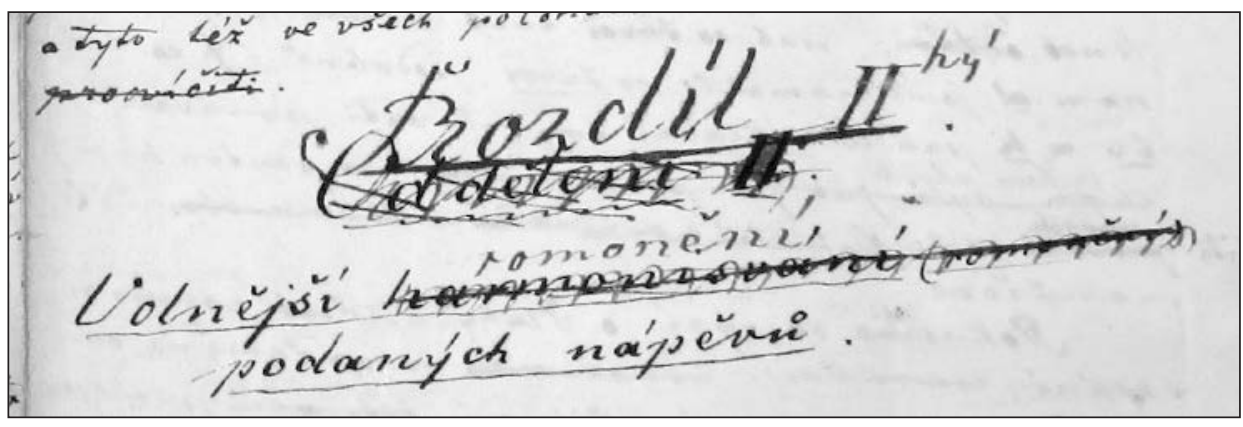

Obr. 2. Ukázka oprav v konceptu Krejčího harmonie.

ve smyslu hudební nauky se ovšem povznášejí kapitoly o modulaci (přetonadování) a melodických tónech.

Modulace je relativně do hloubky rozebrána, včetně jevi̊ jako modulace skokem (záskočné přetonadováni) a jejího významu v hudební formě nebo možnosti modulovat jedním akordem do více tónin (typicky samozřejmě různým přehodnocením zmenšeně-zmenšeného septakordu - vícestranné přetonadováni). V sousedství modulací jsou vyloženy i prríklady volnějších rozvodů a překvapivě teprve nyní různé možnosti klamných závěrů (záluda).

Velmi detailně jsou probrány melodické tóny a jejich užití. Prodlevu, uvažovanou pouze v basu, nazývá Krejčí členitón (ve smyslu „sčlenění více akordů nad jedním basem“), tužkou je připsána i nám asi bližší varianta - průtón. Př́držka je průtah, věštní tón předjímka. Střídavý tón a průchod použivá Krejčí ve tvarech shodných s dnešním názvoslovím (včetně atributů chromatický a diatonický). Vrcholně zajímavé je použití teorie neakordických melodických tónů $\mathrm{k}$ náznakům teorie budování dalších rodin akordů, které bychom už v dnešním systému vysvětlovali jako alterace.

Pozornost zasluhuje i přítomnost výkladu o sledu mimotonálních dominant a sekvencích neutrálních septakordů a nonakordů. Obecně je důraz kladen i na harmonizaci melodie.

Př́kladů z literatury se sice $\mathrm{v}$ konceptech mnoho nevyskytuje, ale např́íklad Händelovo nebo Mozartovo jméno padne. Krejčí se dotkne i harmonické analýzy (romonozpytné rozluštěni príkladĩ).

Za koncepty Nauky o romonu je pak přiložen dosud neznámý a v literatuře nepopsaný, krátký koncept Nauky o nápěvu a českého Pojednání o nápěvu. K zákonitostem, které $\mathrm{v}$ melodii indukuje harmonie (charakter tónin podle předznamenání, modulace v melodii) zde Krejčí přidává i základy nauky o rytmu a metru. Stále se drží Amerlingova názvosloví. 


\section{Závěrem}

Závěr z několika předchozích odstavců je zřejmý: už těsně před polovinou 19. století vznikla v Praze vcelku velmi vyspělá česká učebnice harmonie. Nutně se nabízí otázka, proč nikdy nevyšla? Lze se domnívat, že za touto skutečností stojí změna jak pracovních vztahů dvojice Krejčí-Amerling, tak pochopitelně společensko-politické změny boư̌livých let 1848 a 1849 i následujícího desetiletí. Připomeňme, že se Krejčí pod nejširší a patrně úplnou verzi konceptu učebnice podepsal právě počátkem léta roku 1849.

Amerlingova osobnost už léta činného a v Praze známého pedagoga poskytovala tehdy teprve osmadvacetiletému Krejčímu záštitu a - je-li údaj u Douchy správný - pak i nutnou finanční podporu. Tato pomoc ovšem velmi pravděpodobně mohla být i zárodkem neúspěchu. Amerlingův pokus o vybudování vlastního moderního učiliště skonal na prahu 40. let také za přispění rakouské policie. Pro Krejčího učebnici nemohlo být spojení s otevřeně národovecky smýšlející osobností s takovouto skvrnou kolem roku 1850 dobrým doporučením pro oficiální místa.

Navíc nutně muselo postupně docházet $\mathrm{k}$ stále větším odklonům osobních filozofíi jakkoli neuvěřitelně vzdělaného, přesto zarytého fantasty Amerlinga a Josefa Krejčího, známého ve zralejším věku zejména svým konzervatismem. Nasvědčuje tomu i citát z Amerlingova dopisu, na který vzpomíná Josef Bohuslav Foerster: „Bože! Tisíc věcí bych měl s hudebniky, co mluvit, a Foerster před slávou do lesư uteče, a Krejči do krejčoven [...] a tak mnoho povolaných a málo včas vyvolených!“. ${ }^{18}$ Amerlingův zápal byl sice více než prríkladný, ovšem často - a zdaleka ne jen na hudebním poli - právě toto nadšené zapálení bránilo praktickému uskutečnění plánů v rozumných mezích. Pro př́klad stačí sáhnout k nastíněnému systému názvosloví. To je sice po stránce jazykové téměř nepřirozeně čisté, nicméně až zoufale nepraktické (tónec - tónika, tónice - dominanta apod.).

Smělý plán ředitele české hlavní školy Karla Slavoje Amerlinga a jeho učitele varhanictví a harmonie Josefa Krejčího, který by ve svém výsledku snad mohl vedle konzervatoře a varhanické školy vytvořit „třetí kolej“ teoretického vzdělávání u nás, neuspěl.

Závěrem zbývá naznačit, že možnosti zkoumání Krejčího pozůstalosti nejsou vyčerpány a ani nadále nejsou bez zajímavosti. Upozorňuji např́klad na podobnost nezvěstného pramene N-11 popsaného Jitkou Ludvovou, ${ }^{19}$ tedy Karl Franz Pitsch - Jan Josef Čejka: Hudebni teorie pro druhý ročník varhanické školy (mělo by se jednat o Čejkův překlad Pitschova německého originálu vzniklého pro druhý ročník školy roku 1856), s textem Theoretischer Lehrkurs an der Prager Organistenschule, II. Jahrgang, Schuljahr 1856 - verfaßt von J. Krejči.

18 FOERSTER, Josef Bohuslav. Co život dal. Praha: Leopold Mazač, 1942.

19 LUDVOVÁ, Jitka. Česká hudební teorie 1750-1850. s. 104. 
Přisouzení originálu Pitschovi (Píčovi) na základě Zvonařova hesla Pitsch v Riegrově slovníku ${ }^{20}$ nemusí být správné.

Viktor Hruška (hruska.viktor@hamu.cz), Výzkumné centrum hudební akustiky, HAMU, Katedra teorie a dějin hudby, HAMU, Praha.

\section{ABSTRACT \\ REDISCOVERY OF ONE OF THE OLDEST HARMONY TEXTBOOKS IN CZECH LANGUAGE}

Discovery of the autograph of harmony textbook by Josef Krejčí (1822-1881) which was considered missing is described as well as the authorship issues. By various means, it is documented that Josef Krejčí actually was the author of the text. The suggested exclusive authorship of Karel Slavoj Amerling (1807-1881) is excluded, although the cooperation of these two personalities is almost certain. The contents of the historical autograph is described and discussed.

\section{Key words}

Josef Krejčí, Karel Slavoj Amerling, Czech music in 19th century, history of Czech music theory

\section{Bibliography}

\section{Sources}

Pozůstalost Josefa Krejčiho. Uložena v archivu pražské konzervatoře.

Hudba českoslovanská. Pramen uložený části pozůstalosti Karla Slavoje Amerlinga spravované Literárním archivem Památníku národního písemnictví.

AMERLING, Karel Slavoj. Př́íspěvek k mudřectví hudebnímu dle Frančana Fétise. Jindy a nyní. $1833,8-9$.

AMERLING, Karel Slavoj. O hudbě z hlediště vychovatelského. Posel z Budče. 1848, 48-52.

\section{Literature}

FOERSTER, Josef Bohuslav. Co život dal. Praha: Leopold Mazač, 1942.

HOFFMANNOVÁ, Eva. Karel Slavoj Amerling. 2. vyd. Brandýs nad Orlicí: Knihkupectví U Podléšky, 2003. ISBN 80-902-9613-0.

HRUŠKA, Viktor. Dílo vybraných osobností počátků dějin české hudebni teorie. Praha, 2013. Diplomová práce. HAMU.

HRUŠKA, Viktor. Karel Slavoj Amerling v kontextu své doby. Živá hudba. 2012, č. 3.

LUDVOVÁ, Jitka. Česká hudebni teorie 1750-1850. Praha: Academia, 1985.

LUDVOVÁ, Jitka. Česká hudební teorie novéjši doby, 1850-1900. Praha: Academia, 1989.

ŠíN, Otakar. Teoretikové v řadě ředitelů pražské konzervatoře. In Sborník na pamět’ 125 let konzervatoře hudby v Praze. Praha: Vyšehrad, 1936, s. 165-178. 
